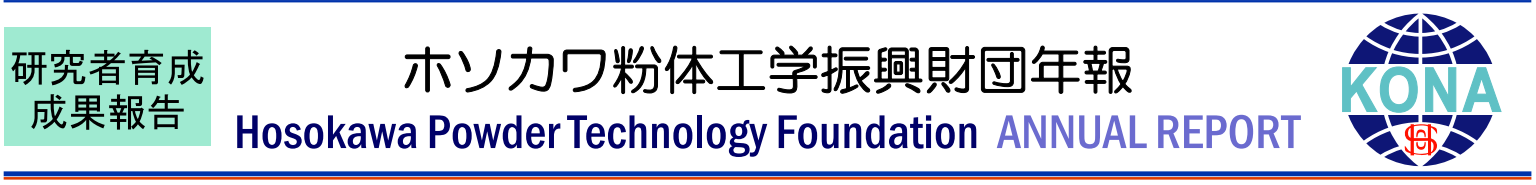

15503

\title{
誘電率による微粒子複合材料内粒子分散状態の計測 \\ Estimation of the Filler Dispersion States in the Composite Materials by Permittivity
}

\author{
援助対象者 Scholarship Student: 久志本 築 Kizuku KUSHIMOTO \\ 東北大学大学院環境科学研究科 博士課程後期 1 年 \\ Graduate School of Environmental Studies, Tohoku University, PhD Student (D1) \\ E-mail: kizuku@mail.tagen.tohoku.ac.jp
}

\begin{abstract}
研究指導者 Academic Leader: 加納 純也 Junya KANO
教授, Professor

E-mail:kano@tagen.tohoku.ac.jp
\end{abstract}

\section{成 果 の 概 要}

\section{1. 緒言}

無機酸化物微粒子, 高分子材料の発展は目覚 しく，それに伴い，これら二つの材料の性質を 組み合わせることが可能な微粒子複合材料の需 要が急速に拡大している。この微粒子複合材料 の機能の発現や性能の向上は, 一般に, 微粒子 の分散状態を改善することで可能となる。 その ため, この分散状態を評価することは, 微粒子 複合材料のプロセス設計や品質管理において, 非常に重要といえる。ここで, 現在行われてい る微粒子分散状態の評価法調べると, 各種顕微 鏡を用いた直接観察法や小角 $\mathrm{X}$ 線散乱法など が挙げられる ${ }^{[1]}$. しかしながら, 直接観察法で は非破壊での観察が困難であり，材料全体を評 価するためには大量の観察点が必要となり, 小 角 X 線散乱法では多重散乱の影響などから高 濃度での評価が難しい. そのため, 微粒子分散 状態の非破壊かつ定量的な評価手法の開発は急 務である。
そこで, 本研究では, 微粒子分散状態が材料 物性に影響を及ぼすことを逆に利用し，材料物 性から微粒子分散状態を計測できるのではない かと考えた。 また，実用的かつ沉用的な計測方 法を目指し, 材料物性の中でも, 微粒子の微視 構造に鋭敏に変化し，計測が非破壊，迅速，簡 便かつ定量的な誘電率を用いることとした。 今 回は，その第一段階として粒子径分布の誘電率 への影響を既に提案された式による計算值と実 測值を比較することで検討した。

\section{2. 誘電率推算における理論式}

微粒子分散系における誘電率の推算式は, い 〈つか報告されており，その中でも今回は以下 に示す代表的な2つの推算式を用い, モデル系 における実験結果とそれぞれ比較した。

一つ目に誘電率の推算によく用いられるもの として Power law model ${ }^{[2]}$ が挙げられ, 以下の Eq.（1）で表される.

$$
\varepsilon^{\beta}=p_{\mathrm{f}} \varepsilon_{\mathrm{f}}^{\beta}+\left(1-p_{\mathrm{f}}\right) \varepsilon_{\mathrm{m}}^{\beta}
$$


ここで， $\varepsilon, \varepsilon_{\mathrm{f}}, \varepsilon_{\mathrm{m}}$ はそれぞれ，微粒子複合材 料の誘電率, フィラー粒子の誘電率, 母材の誘 電率を表し, $p_{\mathrm{f}}$ はフィラー粒子の体積含有率で ある. また, $\beta$ は任意の值を取る無次元数である。

二つ目に，球形粒子分散系に打ける誘電率の 理論式として, Wagner の理論式 ${ }^{[3]}$ が挙げられ, 以下の Eq. (2) で示される.

$$
\frac{\varepsilon-\varepsilon_{\mathrm{m}}}{\varepsilon+2 \varepsilon_{\mathrm{m}}}=\frac{\varepsilon_{\mathrm{f}}-\varepsilon_{\mathrm{m}}}{\varepsilon_{\mathrm{f}}+2 \varepsilon_{\mathrm{m}}} \Phi
$$

ここで, $\Phi$ はフラー粒子の体積含有率である.

\section{3. 実験結果および考察}

既存の提案式から，微粒子複合材料における 巨視的な誘電率が粒子径分布の影響されるかを 検討するために, 粒子径分布の幾何標準偏差 $\sigma_{\mathrm{g}}$, フィラーと母材の誘電率の大小関係が異な るサンプルについて誘電率を実測し, Eq. (1), （2）による計算值と比較した，各サンプルで使 用した材料とその物性は以下の Table 1 にまと めた，各サンプルにおけるフィラー粒子は，完 全に分散した状態となるように配置し，その後 フィラー粒子の配置を固定するために母材を硬 化させた，比誘電率の測定には，平行平板キャ パシタンス法により測定した。 印加電流は電圧 $1.00 \mathrm{~V}$, 周波数 $100 \mathrm{kHz}$ の交流電流とした.また, 母材の誘電率はブランクの実測值を用い, フィ ラーの誘電率は文献值 ${ }^{[4]}$ を用いた。

まず, Sample 1 の実験結果と Power law model による誘電率の推算式 Eq. (1) の $\beta$ を変 更した際の計算値を比較したところ Fig. 1 とな り， $\beta=0.1$ のときに推算值と実測值が良好に 一致することが確認された。同様の検討を Sample 2 の実験結果に対しても適用し比較した
ところ Fig. 2 となり, $\beta \rightarrow 0$ としても一致する 值が見つからなかった。このことは $\beta$ は一定值 を用いることはできず，一般的によく用いられ る Power law model では汎用的に誘電率を推算 することは困難であること意味し, 微粒子複合 材料における巨視的な誘電率は単純な統計モデ ルでは推算できないことを表している.

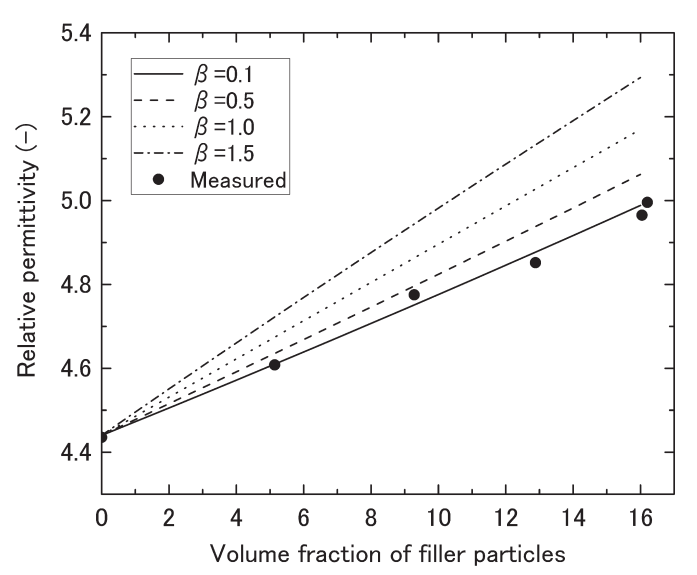

Fig. 1 Comparison with power law model and measured values for sample 1.

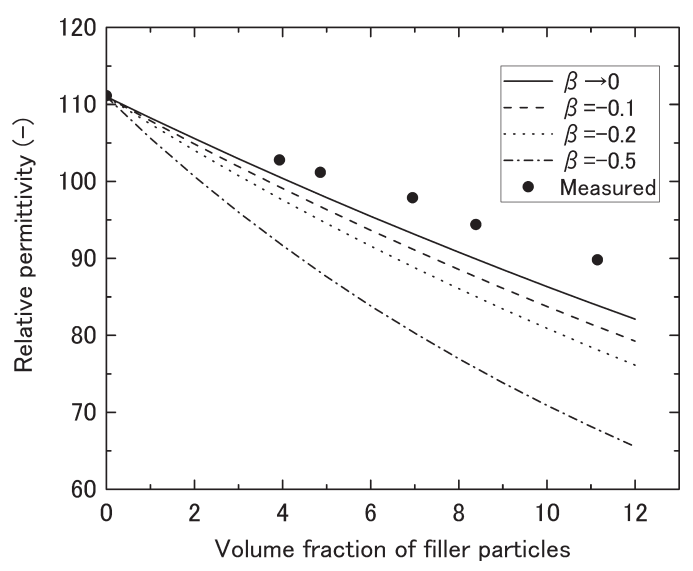

Fig. 2 Comparison with power law model and measured values for sample 2 .

Table 1 Properties of sample materials

\begin{tabular}{cccccccc}
\hline \multirow{2}{*}{ Sample } & Matrix & Filler & $\begin{array}{c}\text { Fraction } \\
{[\text { vol. \%] }}\end{array}$ & $\begin{array}{c}D_{50} \\
{[\mu \mathrm{m}]}\end{array}$ & $\begin{array}{c}\sigma_{\mathrm{g}} \\
{[-]}\end{array}$ & & \multicolumn{2}{c}{$\varepsilon_{\mathrm{r}}[-]$} \\
\hline 1 & Epoxy & $\mathrm{Al}_{2} \mathrm{O}_{3}$ & $0-15.2$ & 5090 & 1.02 & 4.44 & 9.0 \\
2 & Gelatin & $\mathrm{Al}_{2} \mathrm{O}_{3}$ & $0-11.1$ & 1440 & 1.22 & 112 & 9.0 \\
\hline
\end{tabular}


次に, Wagnerの理論式による誘電率の計算 值と実測值を Sample 1，2 それぞれについて比 較したところ Fig. 3，4 となった。 これらのグ ラフから Sample 1 は理論值と実測值が良好に 一致するが, Sample 2 については良好な一致が みられなかった。 ここで, Wagnerの理論式で は粒子同士の相互作用はないと仮定しているこ とを踏まえると考えると, Sample 2 のように粒 子径が小さく, 粒子径分布が存在するような系 では，粒子個数が多くなり，粒子同士の間隔が 相対的に狭くなる場合, 粒子同士の相互作用が 無視できなくなったため実測值との誤差が大き

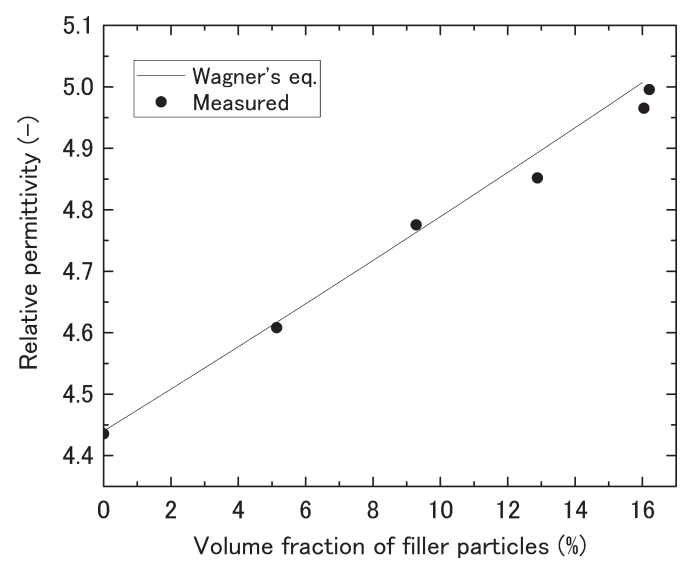

Fig. 3 Comparison with Wagner's theoretical values and measured values for sample 1.

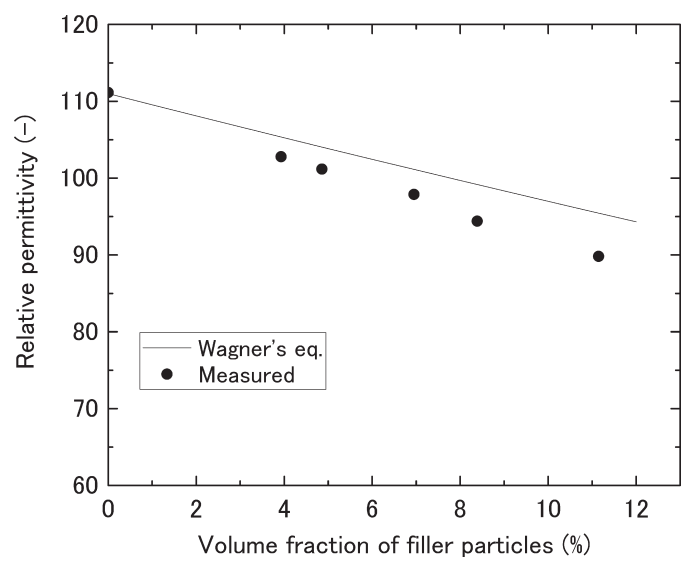

Fig. 4 Comparison with Wagner' $\mathrm{s}$ theoretical values and measured values for sample 2 .
くなったと考えられる。実際の材料では, さら に粒子径も小さく，粒子径分布のばらつきも大 きくなると場合が多いと考えられるため, Wagnerの理論式を用いて誘電率を推算するこ とも難しいといえる.

以上のことから, 微粒子複合材料の巨視的な 誘電率を推算するためには，フィラー粒子の粒 子径分布のばらつきとフィラー粒子径の微細化 に伴う，粒子同士の相互作用を考慮する必要が あることが示唆された。

\section{4. まとめ}

微粒子分散状態はフィラー粒子の粒子径分布 を用いて定量的に評価されるが, 固体材料中に おける非破壊かつ汎用的な計測手法は未だ存在 しない、そこで, 誘電率を用いた粒子径分布測 定手法の開発を目指した。今回は，その第一段 階として, 微粒子複合材料の巨視的な誘電率を 推算する上で考慮すべきパラメータについて, 既存の提案式と比較することで検討した. 結果, 複合材料の誘電率はフィラー粒子の粒子径分布 及び粒子径の影響が無視できないことがわかっ た.このことを逆に考えれば, 微粒子複合材料 において，誘電率と粒子径分布には相関がある ということであり，その関係を推算することが できれば，誘電率から粒子径分布を推算可能で あると想定される。今後はこの関係を推算する 手法を開発し, 微粒子分散状態の新規推算手法 の構築を目指す.

\section{参考文献}

[1] 経済産業省,「ナノ物質の管理に関する検討会（第 3 回）配布資料 2」, 2013, 35 pp.

[2] K. K. Kärkkäinen, A. H. Sihvola and K. I. Nikoskinen, IEEE T Geosci Remote, 2000; 38(3):1303-1308.

[3] 花井哲也, 「不均質構造と誘電率物質をこわさず に内部構造を探る」, 吉岡書店, 2004, 304 pp.

[4]静電気学会, 「新版 静電気ハンドブック」, 株式 会社オーム社, 1998, $1294 \mathrm{pp}$. 


\section{外部発表成果}

\section{口頭・ポスター発表}

1. 久志本 築, 石原 真吾, 加納 純也, 下坂 厚子, 白川 善幸, 日高 重助, “誘電率による微粒 子複合材料に扔けるフィラー粒子分散状態 の高効率計測方法の開発”, 資源素材学会東 北支部平成 28 年度春季大会, 仙台市, （ポ スター, 2016 年 6 月 10 日).

2. 久志本 築, 下坂 厚子, 白川 善幸, 日高 重助,
石原真吾, 加納 純也, 森山 美果, 萱野義貞, “微粒子が分散した複合材料誘電率の推算”, 化学工学会第 48 回秋期大会, 徳島市, (オー ラル, 2016 年 9 月 6 日〜 9 月 8 日, 化学工 学会粒子・流体プロセス部会シンポジウム 賞（プレゼンテーション賞）受賞).

3. 久志本築, 石原 真吾, 加納 純也, 森山 美果, 筬部 周浩, 日高 重助, “誘電率による微粒 子複合材料中フィラーの粒子径分布推算”, 化学工学会第 82 年会, 東京, (オーラル, 2017 年 3 月 6 日 8 日). 